\title{
Deep-sea decapod crustaceans in the western and central Mediterranean Sea: preliminary aspects of species distribution, biomass and population structure*
}

\author{
JOAN B. COMPANY ${ }^{1}$, PORZIA MAIORANO², ANASTASIOS TSELEPIDES ${ }^{3}$, \\ CHRISSI-YIANNA POLITOU ${ }^{4}$, WANDA PLAITY ${ }^{3}$, GUIOMAR ROTLLANT ${ }^{1}$ \\ and FRANCISCO SARDÅ ${ }^{1}$ \\ ${ }^{1}$ Institut de Ciències del Mar (CSIC), Passeig Marítim de la Barceloneta 37-49, 08003 Barcelona, Spain. \\ E-mail: batista@icm.csic.es \\ ${ }^{2}$ Department of Zoology, University of Bari, Via E. Orabona 4, 70125 Bari, Italy. \\ ${ }^{3}$ Institute of Marine Biology, Hellenic Centre for Marine Research, Gournes Pediados, P.O. Box 2214, \\ 71003 Heraklion, Crete, Greece.
}

${ }^{4}$ Institute of Marine Biological Resources, Hellenic Centre for Marine Research, Agios Kosmas, 16604 Helliniko, Greece.

SUMMARY: Three deep-sea areas in the Mediterranean Sea were sampled using a bottom otter trawl during the DESEAS oceanographic survey carried out from early June to early July 2001, covering an area in the western Mediterranean from 600 to $2800 \mathrm{~m}$ in depth and two areas in the central Mediterranean, the western and eastern Ionian Sea from 600 to $4000 \mathrm{~m}$ in depth. Decapod crustaceans were one of the dominant megafaunal groups, together with fishes, in terms of both biomass and abundance. A total of 2799 decapod specimens belonging to 32 species were collected. Abundance and biomass of the decapod crustaceans decreased with depth. For depths below $1000 \mathrm{~m}$, a decrease in total decapod biomass was recorded from west to east. From the data reported in this study and data from the available literature, decapod crustaceans display differential depth distributions in the different areas. For the most abundant species, size and sex distributions versus depth gradient were examined to compare intraspecific population structures between the sampling areas. Despite differences, among areas, in the species' biomass compositions by depth strata and differences in their overall bathymetric ranges of distribution, intraspecific population structures of the most abundant species seem to follow similar trends for size and sex distribution versus depth gradient between the western and central areas. This might be an indication that the individual species structure their populations according to a similar basic pattern regardless of differences in local environmental features. The results have been discussed in the general context of the environmental features encountered by the species in each of the sampling areas.

Key words: deep-sea, Mediterranean, decapod crustaceans, species distribution, population structure.

RESUMEN: CRUSTÁCEOS DECÁPODOS DE PROFUNDIDAD DEL MEDITERRÁNEO OCCIDENTAL Y CENTRAL: ASPECTOS PRELIMINARES SOBRE LA DISTRIBUCIÓN DE ESPECIES, LA BIOMASA Y LA ESTRUCTURA DE POBLACIÓN. - Se muestrearon tres áreas del Mediterráneo profundo con una red de arrastre bentónica durante la campaña oceanográfica DESEAS, desde principios de junio hasta principios de julio de 2001. El rango batimétrico muestreado en el Mediterráneo occidental fue entre los 600 y los $2800 \mathrm{~m}$ de profundidad. Se muestrearon dos áreas del Mediterráneo central, una situada en la parte occidental del Mar Iónico y la otra situada en la parte más oriental del mismo, cubriendo un rango batimétrico entre los 600 y $4000 \mathrm{~m}$ de profundidad. Los crustáceos decápodos fueron uno de los grupos, junto con los peces, dominantes de la megafauna en términos de biomasa y abundancia. Se capturaron un total de 2799 individuos de decápodos pertenecientes a 32 especies. La abundancia y biomasa de los crustáceos decápodos disminuyó con la profundidad. Teniendo en cuenta únicamente las muestras tomadas a profundidades superiores a los $1000 \mathrm{~m}$, se detectó una disminución de la biomasa total de los crustáceos decápo- 
dos en el área de muestreo más oriental (parte oriental del Mar Iónico) con respecto al Mediterráneo occidental (Mar Balear). Los datos aportados en este estudio junto con los datos disponibles en la literatura, indican que los crustáceos decápodos se distribuyen en rangos batimétricos diferentes en cada una de las áreas de estudio. Aunque se encontraron diferencias entre las áreas de estudio, en la distribución de biomasa con respecto a la profundidad y en los rangos batimétricos de cada especie, la estructura de población de las especies más abundantes parece seguir la misma tendencia por lo respecta la distribución batimétrica de sexos y tamaño de sus individuos en toda el área geográfica muestreada. Este último aspecto podría ser una indicación de que las especies estructuran sus poblaciones de acuerdo a un patrón similar, independientemente de las diferencias locales del ambiente. Los resultados se han discutido bajo el contexto general de las características ambientales encontradas por cada especie en cada una de las áreas de muestreo.

Palabras clave: Mar profundo, Mediterráneo, crustáceos decápodos, distribución de especies, estructura de la población.

\section{INTRODUCTION}

Decapod crustaceans are one of the dominant megafaunal groups in the deep-sea communities of the Mediterranean Sea (Abelló et al., 1988; Cartes and Sardà, 1992; Sardà et al., 1994). The relatively oligotrophic nature of Mediterranean waters has been presented as one of the environmental factors contributing to the high abundance of decapod crustaceans in comparison with other oceans, in which other megafaunal invertebrates, chiefly echinoderms, predominate (Tyler and Zibrowius, 1992; Sardà et al., 1994). However, though the Mediterranean is a relatively small sea compared with other oceans, existing data and our understanding of the continental margins at depths below 2000 $\mathrm{m}$ lags behind.

Community assemblages and boundaries as well as depth ranges of deep-sea species dwelling along the continental margins have been described in several regional seas of the Mediterranean (Abelló and Valladares, 1988; Cartes and Sardà, 1993; Pipitone and Tumbiolo, 1993; Ungaro et al., 1999; Kallianiotis et al., 2000), but no comparative work dealing with species composition and community structures in the Mediterranean basin as a whole is available. To the authors' knowledge, the only comparative studies dealing with the biomass distribution and population characteristics of commercial demersal resources have recently been carried out down to $800 \mathrm{~m}$ depth within the framework of the MEDITS international Mediterranean trawl survey (see Abelló et al., 2002b). What is more, the few extant comparative studies have neglected to make global comparisons of intraspecific population structures such as size and sex distribution with depth.

The object of this study was to compare the decapod biomass, species composition and population characteristics of deep-sea decapod crustaceans at several sites sampled during the DESEAS project in the continental margins of the western and central Mediterranean down to the abyssal plain at a depth of $4000 \mathrm{~m}$ in the Ionian Sea. Its purpose was to determine whether intraspecific population characteristics, namely size and sex distribution by depth, followed similar patterns at each local site sampled or, in contrast, the population structure of the individual species differed at each location.

\section{MATERIALS AND METHODS}

A total of 26 effective hauls (DESEAS project survey) were conducted at several locations in the western and central Mediterranean Sea from early June to early July 2001 (Fig. 1; Table 1). The sites and depth ranges sampled were: western Mediterranean from 600 to $2800 \mathrm{~m}$ depth in the Balearic Sea south of the island of Mallorca, and central Mediterranean from 600 to $4000 \mathrm{~m}$. Two regions were sampled in the central Mediterranean: the western Ionian Sea off the Calabrian coast and eastern Ionian Sea south of the Peloponnesian Peninsula. The two deepest hauls (3300 and $4000 \mathrm{~m}$ depth; Table 1) were conducted on the abyssal plain of the western Ionian Sea. Because of the bathymetric exceptionality of the two trawls, never before conducted in the Mediterranean with a benthic otter trawl, and because of their geographical distance from the Calabrian coast, these trawls were taken in this study as separate samples. Hauls were conducted using the bottom otter trawl "Maireta" (Sardà et al., 1998). Cod-end mesh size was $40 \mathrm{~mm}$ stretched, covered by a cod-end cover with a mesh size of 12 $\mathrm{mm}$ stretched.

The catch taken in each haul was separated by species. Individuals of each species were counted and separated by sex, and carapace length was measured (CL to the nearest $0.1 \mathrm{~mm}$ ). Species abundance and biomass were calculated both in number and in grams per $\mathrm{km}^{2}$ of the swept area. The swept area was based on trawl duration and on measurements of the gear opening obtained using remotely controlled Scanmar sensors down to a depth of 1500 


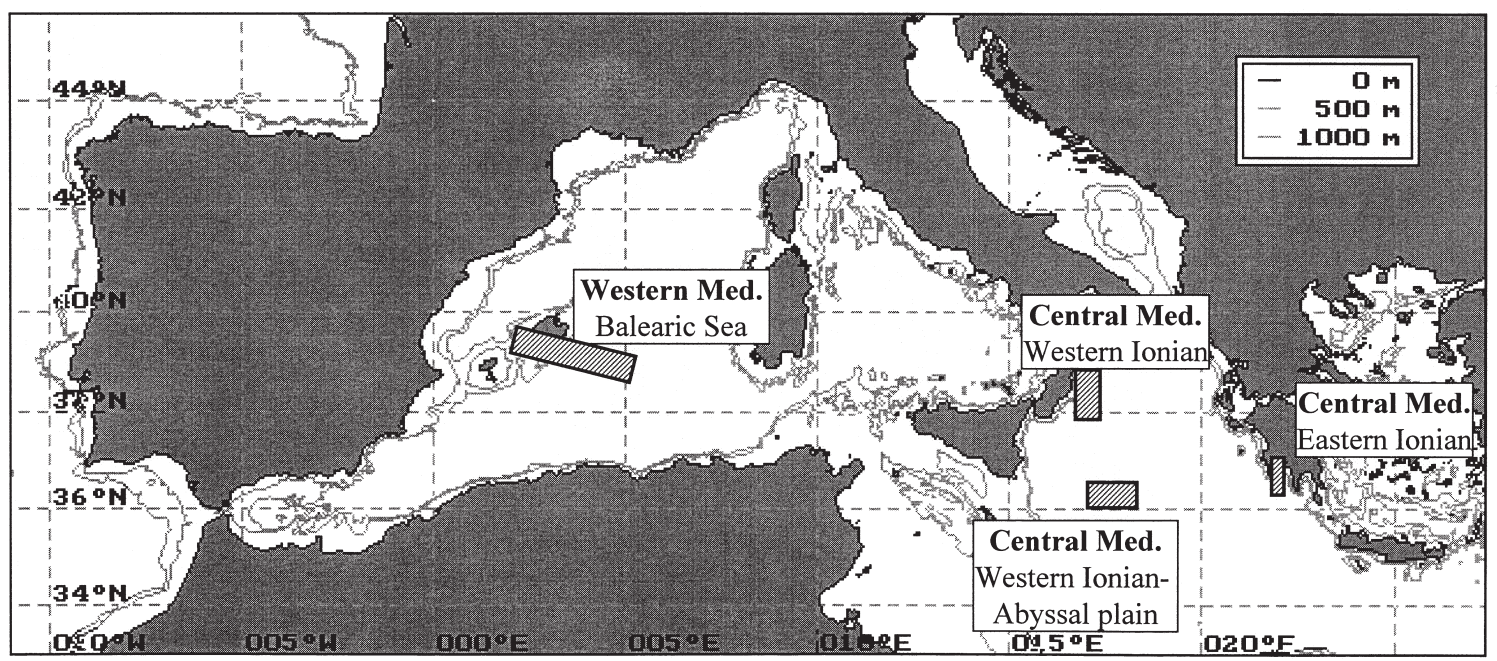

FIG. 1. - Study area surveyed during the DESEAS project.

$\mathrm{m}$ (below which the sensors fail because of the pressure). Below $1500 \mathrm{~m}$ depth, the swept area was based on trawl duration and on the average gear opening obtained at shallower depths.

In order to compare the depth ranges of the most abundant deep-sea decapod species in the different areas, the shallowest depths of the distribution ranges were obtained from the literature.
In view of the small number of samples available from this study and the gaps in the depth range between the hauls (sometimes over $500 \mathrm{~m}$ ), it was not attempted to perform cluster analysis to describe species communities or assemblages. Instead, three depth intervals were established following in part the current literature on these depth ranges, which was only available for the western Mediterranean

TABLE 1. - Characteristics of the hauls performed during the DESEAS survey.

\begin{tabular}{|c|c|c|c|c|c|c|}
\hline \multirow[t]{2}{*}{ Sampling area } & \multirow[t]{2}{*}{ Haul code } & \multirow[t]{2}{*}{ Date } & \multirow[t]{2}{*}{ Depth (m) } & \multicolumn{2}{|c|}{ Starting position } & \multirow[t]{2}{*}{ Haul duration (h) } \\
\hline & & & & Latitude $(\mathrm{N})$ & Longitude (E) & \\
\hline \multirow[t]{7}{*}{ Balearic Sea } & 0 & 06 June & 1200 & $40^{\circ} 48^{\prime} 30^{\prime \prime}$ & $1^{\circ} 48^{\prime} 13^{\prime \prime}$ & 1.30 \\
\hline & 1 & 07 June & 600 & $38^{\circ} 36^{\prime} 51^{\prime \prime}$ & 1'53'29”' & 1.16 \\
\hline & 2 & 08 June & 800 & $38^{\circ} 30^{\prime} 13^{\prime \prime}$ & $1^{\circ} 49^{\prime} 12^{\prime \prime}$ & 1.06 \\
\hline & 3 & 08 June & 1000 & $38^{\circ} 28^{\prime} 47^{\prime \prime}$ & $1^{\circ} 53{ }^{\prime} 20^{\prime \prime}$ & 1.40 \\
\hline & 4 & 08 June & 1500 & $38^{\circ} 17^{\prime} 15^{\prime \prime}$ & $1^{\circ} 48^{\prime} 10^{\prime \prime}$ & 1.13 \\
\hline & 5 & 09 June & 2500 & $38^{\circ} 15^{\prime} 57^{\prime \prime}$ & $2^{\circ} 21^{\prime} 10^{\prime \prime}$ & 2.28 \\
\hline & 6 & 10 June & 2800 & $38^{\circ} 04^{\prime} 01^{\prime \prime}$ & $5^{\circ} 27^{\prime \prime} 04^{\prime \prime}$ & 2.30 \\
\hline \multicolumn{7}{|l|}{ W. Ionian Sea } \\
\hline \multirow[t]{8}{*}{ Calabrian coast } & 7 & 14 June & 600 & $38^{\circ} 18^{\prime} 50^{\prime \prime}$ & $16^{\circ} 37^{\prime} 28^{\prime \prime}$ & 1.11 \\
\hline & 8 & 14 June & 800 & $38^{\circ} 16^{\prime} 56^{\prime \prime}$ & $16^{\circ} 37^{\prime} 32^{\prime \prime}$ & 0.95 \\
\hline & 9 & 15 June & 1000 & $38^{\circ} 15^{\prime} 11^{\prime \prime}$ & $16^{\circ} 34^{\prime} 44^{\prime \prime}$ & 1.48 \\
\hline & 10 & 15 June & 1500 & $38^{\circ} 10^{\prime} 16^{\prime \prime}$ & $16^{\circ} 38^{\prime} 34^{\prime \prime}$ & 2.00 \\
\hline & 11 & 16 June & 2000 & $37^{\circ} 42^{\prime} 18^{\prime \prime}$ & $16^{\circ} 40^{\prime} 07^{\prime \prime}$ & 1.16 \\
\hline & 12 & 17 June & 1500 & $38^{\circ} 12^{\prime} 07^{\prime \prime}$ & $16^{\circ} 43^{\prime} 52^{\prime \prime}$ & 1.08 \\
\hline & 13 & 18 June & 1200 & $32^{\circ} 13^{\prime} 58^{\prime \prime}$ & $16^{\circ} 35^{\prime} 17^{\prime \prime}$ & 0.33 \\
\hline & 14 & 18 June & 1700 & $38^{\circ} 06^{\prime} 13^{\prime \prime}$ & $16^{\circ} 42^{\prime} 10^{\prime \prime}$ & 1.45 \\
\hline \multirow[t]{2}{*}{ Abyssal plain } & 24 & 01 July & 4000 & $35^{\circ} 41^{\prime} 51^{\prime \prime}$ & $17^{\circ} 47^{\prime} 00^{\prime \prime}$ & 3.00 \\
\hline & 25 & 02 July & 3300 & $36^{\circ} 08^{\prime} 21^{\prime \prime}$ & 16²'09”' & 2.00 \\
\hline \multirow[t]{9}{*}{ E. Ionian Sea } & 15 & 22 June & 600 & $36^{\circ} 47^{\prime} 46^{\prime \prime}$ & $22^{\circ} 04^{\prime} 29^{\prime \prime}$ & 1.00 \\
\hline & 16 & 22 June & 800 & $36^{\circ} 51^{\prime} 52^{\prime \prime}$ & $22^{\circ} 06^{\prime} 16^{\prime \prime}$ & 1.05 \\
\hline & 17 & 22 June & 1300 & $36^{\circ} 42^{\prime} 52^{\prime \prime}$ & $22^{\circ} 10^{\prime} 25^{\prime \prime}$ & 1.00 \\
\hline & 18 & 23 June & 2200 & $36^{\circ} 32^{\prime} 17^{\prime \prime}$ & $22^{\circ} 01^{\prime} 46^{\prime \prime}$ & 2.15 \\
\hline & 19 & 23 June & 2600 & $36^{\circ} 21^{\prime} 05^{\prime \prime}$ & $22^{\circ} 00^{\prime} 06^{\prime \prime}$ & 1.30 \\
\hline & 20 & 24 June & 1100 & $36^{\circ} 44^{\prime} 49^{\prime \prime}$ & $22^{\circ} 07^{\prime} 32^{\prime \prime}$ & 1.15 \\
\hline & 21 & 25 June & 1700 & $36^{\circ} 24^{\prime} 06^{\prime \prime}$ & $22^{\circ} 14^{\prime} 06^{\prime \prime}$ & 1.30 \\
\hline & 22 & 26 June & 800 & $36^{\circ} 51^{\prime} 39^{\prime \prime}$ & $22^{\circ} 06^{\prime} 12^{\prime \prime}$ & 1.15 \\
\hline & 23 & 26 June & 600 & $36^{\circ} 47^{\prime} 43^{\prime \prime}$ & $22^{\circ} 04^{\prime} 28^{\prime \prime}$ & 1.30 \\
\hline
\end{tabular}


waters at depths down to 2200 m (Cartes and Sardà, 1993; Stefanescu et al., 1993). The bathymetric intervals established in this study were: a) from 600 to $1000 \mathrm{~m}$, the middle slope depth range for which the most information is available for the Mediterranean; b) from 1000 to $1500 \mathrm{~m}$, a transitional depth stratum between middle and lower slope assemblages; and c) from 1500 to $2800 \mathrm{~m}$, $2000 \mathrm{~m}$, and $2600 \mathrm{~m}$ (maximum sampled depths of the western, central, and eastern areas of this work, respectively), which were considered as lower slope depths. The two trawls performed at 3300 and 4000 $\mathrm{m}$ were taken as separate samples of the abyssal region due to their geographical location on the abyssal plain in the western Ionian Sea.

Individuals were very scarce in some depth intervals at certain sampling locations, which made it difficult to obtain a representative size frequency distribution. Therefore, in order to be able to compare intraspecific population structures between the depth intervals and the different sampling locations, size frequencies for some species were taken from the literature, bearing in mind that sampling season and sampling method can affect the results. Thus, only studies in which the sampling method was a bottom otter trawl were used. In our view, even the few specimens collected here are of considerable importance given the scarcity of data for the bathyal and abyssal regions available to date.

The sizes below which individuals were considered juveniles were taken from Company (1995), Company and Sardà $(1997,2000)$, Company et al . (2001) and Puig et al. (2001) and also from measurements of the external sex traits, such as the size and shape of the sexual appendage on caridean decapods.

\section{RESULTS}

In terms of total biomass and total abundance, decapod crustaceans and fishes were the dominant megafaunal groups. Although statistical validation of our data was not possible due to the low number of samples available on each bathymetric stratum, the general trend indicates that total fish abundance was higher than total crustacean abundance in the western Mediterranean in the 800 to $1200 \mathrm{~m}$ depth interval (Fig. 2A). Below this depth, fish and crustacean abundance values were similar. In contrast, in the central Mediterranean (western Ionian Sea; Fig. 2B), fish and crustacean abundance were more sim-
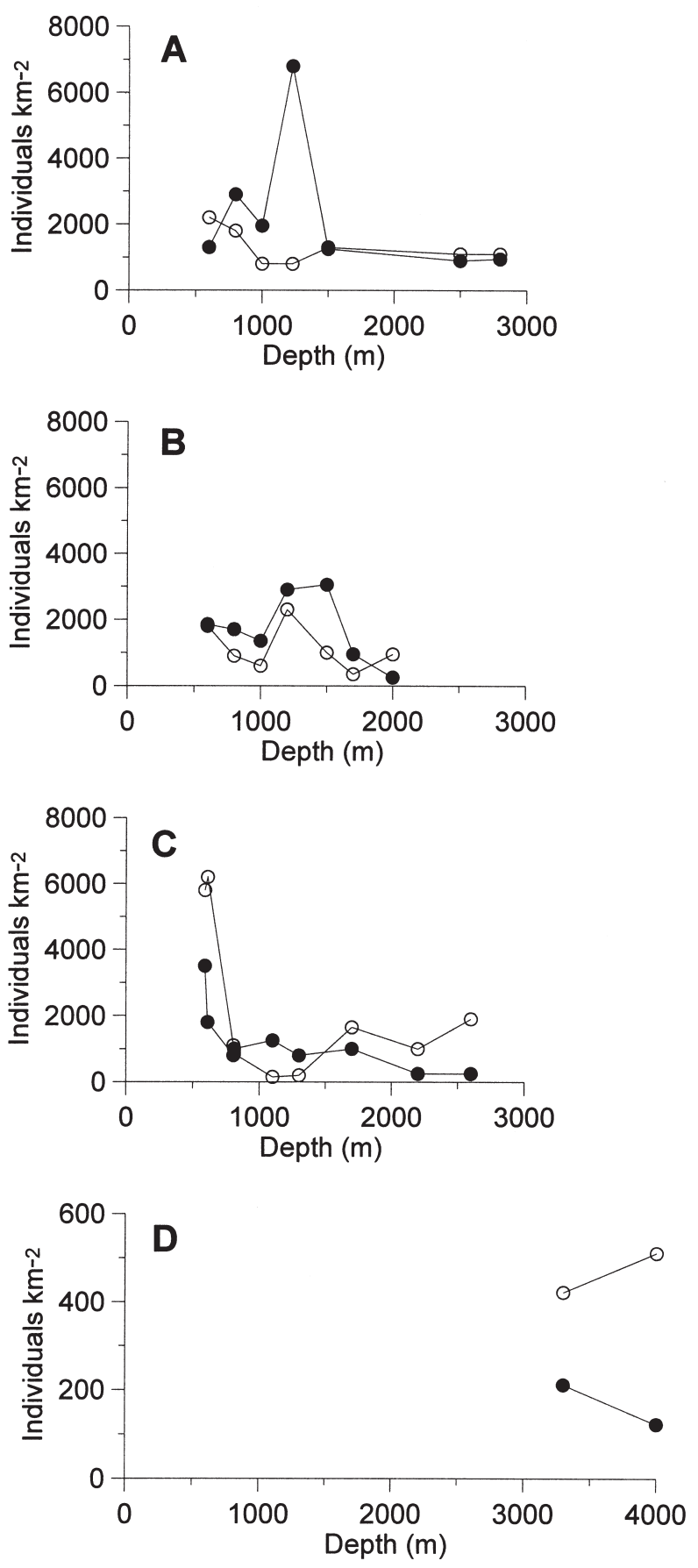

FIG. 2. - Total decapod abundance and total fish abundance over the depth range sampled in this study (number of individuals $\mathrm{km}^{-2}$ ). A, western Mediterranean: Balearic Sea south of the island of Majorca; B, central Mediterranean: western Ionian Sea off Calabrian coast; C, central Mediterranean: eastern Ionian Sea south of the Peloponnesian Peninsula; D, abyssal area: abyssal plain in the western Ionian Sea. Open circle, decapod crustaceans; black circle, fish.

ilar, but fish abundance was still slightly higher than crustacean abundance in the 800 to $1500 \mathrm{~m}$ depth interval. In the easternmost sampled area (eastern Ionian Sea; Fig. 2C), decapod crustaceans attained higher abundance values than fish both at depths 



FIG. 3. - Total decapod abundance, biomass, and individual weight. $\mathrm{A}$, Abundance in number individuals $\mathrm{km}^{-2}$; $\mathrm{B}$, Biomass in grams $\mathrm{km}^{-2}$; C, Biomass in grams $\mathrm{km}^{-2}$ (only samples below $1000 \mathrm{~m}$ were considered); D, mean individual weight (g) per haul. Diamonds, Balearic Sea; Circles, Western Ionian Sea; Crosses, Abyssal Plain (Western Ionian); Squares, Eastern Ionian Sea.

shallower than $800 \mathrm{~m}$ and at depths below $1500 \mathrm{~m}$. In the abyssal region crustacean abundance doubled fish abundance at $3300 \mathrm{~m}$, and this trend was still more pronounced at the maximum depth sampled in this study, $4000 \mathrm{~m}$ (Fig. 2D).

The decapod abundance (number of individuals per $\mathrm{km}^{2}$ ) in each of the sampling areas exhibited the typical decrease with depth observed in the deep-sea environment (Fig. 3A). A similar trend was observed in decapod biomass (Fig. 3B). In the easternmost area (eastern Ionian Sea), a relatively large biomass of the shrimp Aristaeomorpha foliacea was caught at depths of 600-800 $\mathrm{m}$ (Table 2). These catches were substantially higher than those taken in this same depth range in any of the other areas (Fig. 3B). Excluding these shallower samples and thus just taking into account the depth interval below $1000 \mathrm{~m}$ (Fig. 3C), decapod biomass was higher in the western Mediterranean (average biomass of $13653 \mathrm{~g}$ $\mathrm{km}^{-2}$ ) than in the other two areas at similar depths (3685 and $2195 \mathrm{~g} \mathrm{~km}^{-2}$ in the western Ionian Sea and eastern Ionian Sea respectively). Individual weight also decreased with depth (Fig. 3D), with a slight increase at around $2500 \mathrm{~m}$. This increase was due to the relatively high presence of the brachyuran crab Chaceon mediterraneus in the western Mediterranean (see Table 2).

Table 2 and Figure 4 show the abundance, biomass and relative species abundance at the depth strata chosen in this study. These quantitative values are the first report in the Mediterranean below $2200 \mathrm{~m}$. The number of species caught decreased with depth (see western Ionian Sea data in Table 2, where the bathymetric gradient is the largest available in this study). From the data reported here (Table 2 and Fig. 4) and from the data available in the literature (Table 3), the same decapod species occurred throughout the western and central Mediterranean basin below $1000 \mathrm{~m}$ depth. The single exception was Stereomastis sculpta, caught only in the westernmost area (Balearic Sea). However, the absolute and relative abundance of each species differed among the sampling areas and depth intervals. Aristeus antennatus and Aristaeomorpha foliacea are the main examples of this differential abundance among the sampling areas. A. antennatus is the most abundant decapod crustacean in the westernmost site of this study, but the abundance of A. foliacea is low (Table 2). Instead, in the easternmost site of this study (Eastern Ionian Sea), the most abundant decapod species is A. foliacea, but the abundance of $A$. antennatus was much lower. Other species, such as Nematocarcinus exilis, also displayed a differential distribution among the areas, being more abundant in the central and eastern areas than in the western area.

Table 3 lists the upper and lower depth distribution ranges of the most abundant decapod species sampled in this study. The shallowest depth limits for the species were obtained from the literature (see details in the footnotes to Table 3). The main prob- 









FIG. 4. - Relative abundance (in \% of number individuals) of the most abundant deep-sea decapods collected during the DESEAS survey. See exact bathymetric limits of each area in Table 1 . See Table 2 for species codes. Note, on the bathymetric range $600-999$ m species presenting a relative abundance lower than $1 \%$ were grouped as other.

lems faced in seeking to compare the depth ranges of the species were differences in existing knowledge and the sampling effort expended in each of the sampling areas. Strict accuracy in the species' depth distribution ranges presented is highly difficult to achieve, because of gaps in the sampling coverage. Nevertheless, from the data reported in Table 3, the depth distribution ranges of Mediterranean deep-sea decapods would appear to differ between the areas sampled in this study.

Besides relative species abundance and distribution ranges in the different sampling areas, the final aspect considered in this study was whether or not the population structure of each individual species followed similar trends in all the sampling areas. Figures 5 and 6 shows the size frequencies and sex distribution by depth interval for the two most abundant deep-sea decapods in the Mediterranean Sea, namely Acanthephyra eximia (Fig. 5), and Nematocarcinus exilis (Fig. 6).

Juveniles of Acanthephyra eximia were mainly found in the deepest part of the range (below 2000 $\mathrm{m}$ ) in each of the sampling areas of the western and central Mediterranean (Fig. 5). The maximum depth sampled in the central area was $2000 \mathrm{~m}$, and no small individuals were observed. 
TABLE 3. - Depth ranges (m) for the most abundant deep-sea decapod crustaceans dwelling in the Western and Central Mediterranean Sea sampled close to the bottom by means of bottom otter trawls.

\begin{tabular}{|c|c|c|c|c|}
\hline \multirow[t]{2}{*}{ Species } & \multirow[t]{2}{*}{ Balearic Sea } & \multicolumn{2}{|c|}{ Western Ionian Sea } & \multirow{2}{*}{ Eastern Ionian Sea } \\
\hline & & Calabrian coast & Abyssal plain & \\
\hline \multicolumn{5}{|l|}{ Suborder Dendrobranchiata } \\
\hline \multicolumn{5}{|l|}{ Infraorder Penaeidea } \\
\hline \multicolumn{5}{|l|}{ Family Aristeidae } \\
\hline Aristaeomorpha foliacea & $273^{2}-748^{2}$ & $250^{6}-772^{6}$ & n.r. & $388^{7}-1047^{1}$ \\
\hline Aristeus antennatus & $414^{5}-2800^{1}$ & $255^{6}-2000^{1}$ & Down to $3300^{1}$ & $480^{7}-1700^{1}$ \\
\hline \multicolumn{5}{|l|}{ Suborder Pleocyemata } \\
\hline \multicolumn{5}{|l|}{ Infraorder Caridea } \\
\hline \multicolumn{5}{|l|}{ Family Oplophoridae } \\
\hline Acanthephyra eximia & $421^{5}-2800^{1}$ & $710^{6}-2000^{1}$ & Down to $4000^{1}$ & $897^{7}-2600^{1}$ \\
\hline Acanthephyra pelagica & $506^{5}-2800^{1}$ & $596^{6}-2000^{1}$ & Down to $4000^{1}$ & $480^{7}-1192^{7}$ \\
\hline \multicolumn{5}{|l|}{ Family Pandalidae } \\
\hline Plesionika martia & $267^{5}-871^{2}$ & $113^{6}-772^{6}$ & n.r. & $262^{8}-1085^{7}$ \\
\hline Plesionika acanthonotus & $421^{5}-1749^{3}$ & $331^{6}-1000^{1}$ & n.r. & $317^{7}-1047^{7}$ \\
\hline \multicolumn{5}{|l|}{ Family Nematocarcinidae } \\
\hline Nematocarcinus exilis & $1094^{4}-2800^{1}$ & $1500^{1}-2000^{1}$ & Down to $4000^{1}$ & $1700^{1}-2600^{1}$ \\
\hline \multicolumn{5}{|l|}{ Infraorder Palinura } \\
\hline \multicolumn{5}{|l|}{ Family Polychelidae } \\
\hline Polycheles typhlops & $241^{5}-1949^{3}$ & $255^{6}-2000^{1}$ & n.r. & $328^{7}-2200^{1}$ \\
\hline Stereomastis sculpta & $803^{4}-2800^{1}$ & n.r. & n.r. & n.r. \\
\hline \multicolumn{5}{|l|}{ Infraorder Brachyura } \\
\hline \multicolumn{5}{|l|}{ Family Geryonidae } \\
\hline Geryon longipes & $335^{5}-1947^{3}$ & $495^{6}-739^{6}$ & n.r. & $644^{7}-1300^{1}$ \\
\hline Chaceon mediterraneus & $2261^{3}-2800^{1}$ & n.r. & Down to $3300^{1}$ & $1700^{1}-2200^{1}$ \\
\hline
\end{tabular}

n.r., not reported; ${ }^{1}$, new depth record after this study; ${ }^{2}$, Abelló et al. (1988); ${ }^{3}$, Cartes and Sardà (1992); ${ }^{4}$, Maynou and Cartes (2000); ${ }^{5}$, Abelló et al. (2002); ${ }^{6}$, Maiorano (unpublished data); ${ }^{7}$, Politou et al. (in press); ${ }^{8}$, Politou et al. (2000).

Note: Acanthephyra eximia was sampled in the Aegean Sea as shallow as $250 \mathrm{~m}$ depth by midwater trawls (Koukouras, 2000) and, in the south coast of Crete, as deep as $3500 \mathrm{~m}$ by benthic baited traps (Christiansen, 1989). Chaceon mediterraneus was caught in the Eastern Mediterranean (off Crete) from $2230 \mathrm{~m}$ to $3028 \mathrm{~m}$ depth by benthic baited traps (Koukouras et al., 2000). These bathymetric records are not considered in this table not only because its geographical distribution differs from the study area of this study but also because the sampling methods differ from the ones used in this study, i.e. bottom otter trawls.

Individuals of Nematocarcinus exilis were relatively scarce in all of the sampling areas. In any case, no previous information on this species has been reported for deep-sea Mediterranean waters at all. For this reason, it was difficult to establish any clear findings on the population structure of this species in any of the areas, except for a slight tendency for the smallest individuals to be aggregated in the deepest part of the range (Fig. 6).

\section{DISCUSSION}

The west-east productivity gradient reported in the Mediterranean Sea (Psarra et al., 2000; Tselepides et al., 2000, 2004) is an environmental feature that needs to be taken into account when one is comparing both the species distribution and the population characteristics considered in this study. Thus, the relative abundance of decapods vs. fish found among the sampling areas might be correlat- ed to this west-east gradient. Decapods are much more abundant than other invertebrate groups in the Mediterranean, in contrast to more productive oceans like the Atlantic, where echinoderms are the dominant invertebrate group (Lampitt et al., 1986; Tyler and Lampitt, 1988; Tyler and Zibrowius, 1992; Sardà et al., 1994). Although no specific literature relating oligotrophy with decapod crustacean biomass is available, it has been suggested that decapods might be more competitive than other invertebrate or vertebrate megafauna in oligotrophic environments (Sardà et al., 1994; Maynou and Cartes, 2000). Our results are consistent with this suggestion, in that the abundance of decapods was higher than that of fishes (see Fig. 2 for depths below $1500 \mathrm{~m}$ ) in the less productive waters in the eastern Ionian Sea (Tselepides et al., 2004). Like the above-mentioned west-east productivity gradient, increasing depth has also been positively correlated with a marked decrease in global productivity (Gage and Tyler, 1991 and citations therein). Along these 
BALEARIC SEA
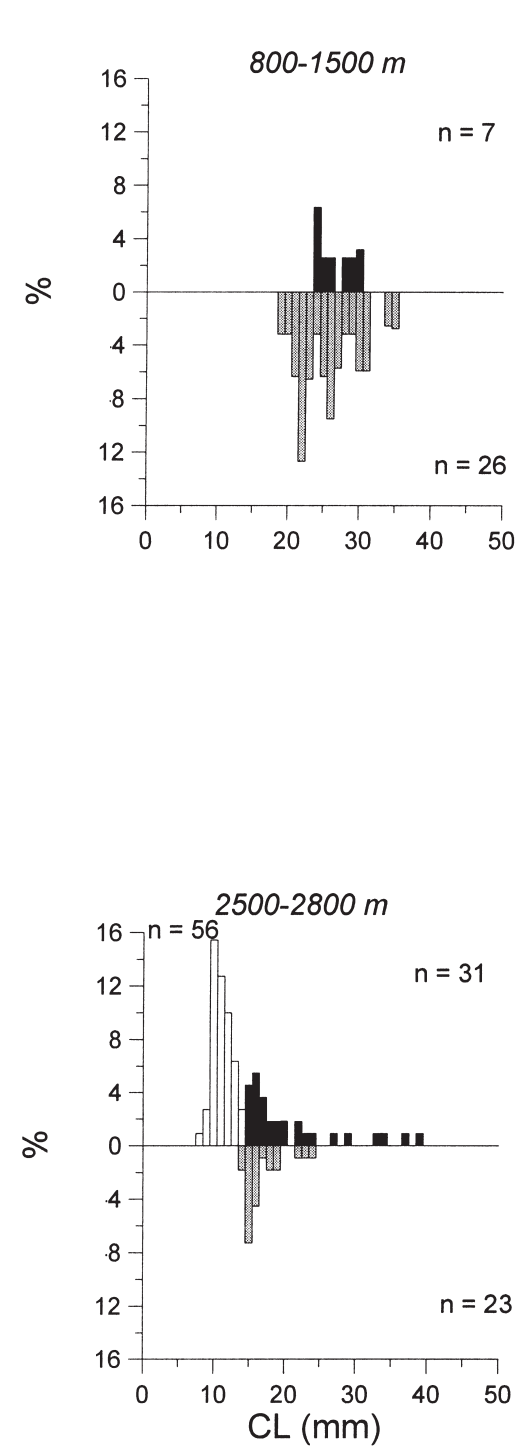

WESTERN IONIAN SEA

Calabrian Coast

$1000-1500 \mathrm{~m}$

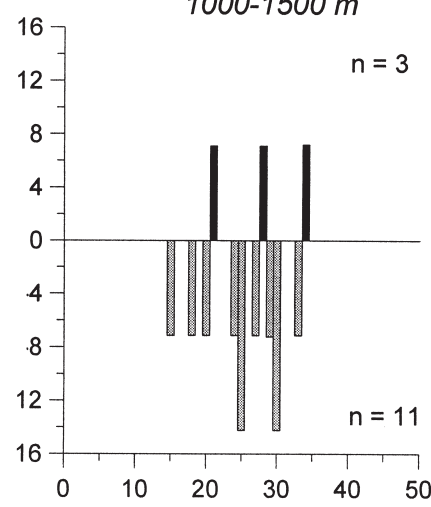

$1700-2000 m$
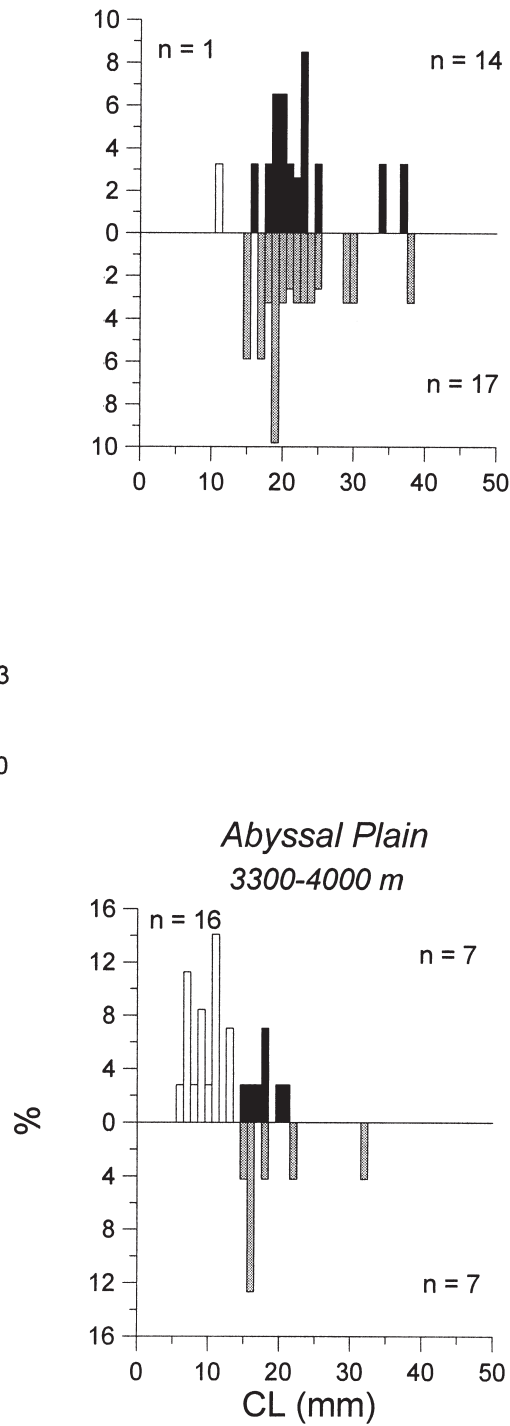

dwelling below $1000 \mathrm{~m}$ depth in the western and central Mediterranean Sea. White bars, indeterminate sex individuals; black bars, males; grey bars, females; $n$, number of individuals. 


\section{BALEARIC SEA}
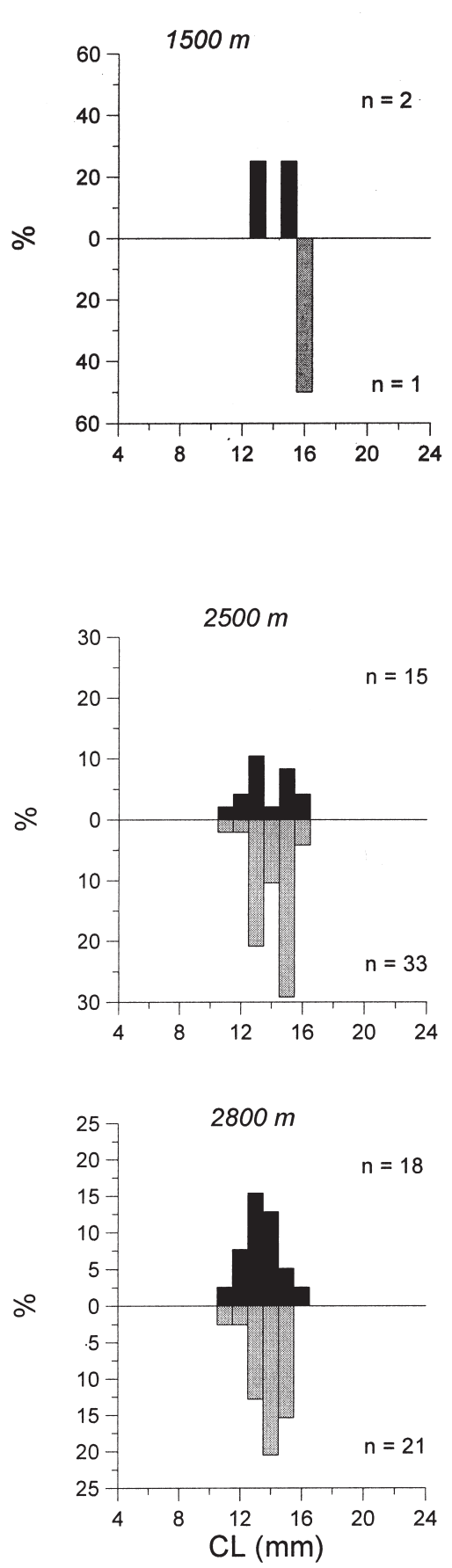

WESTERN IONIAN SEA

Calabrian Coast

$1500-1700 \mathrm{~m}$
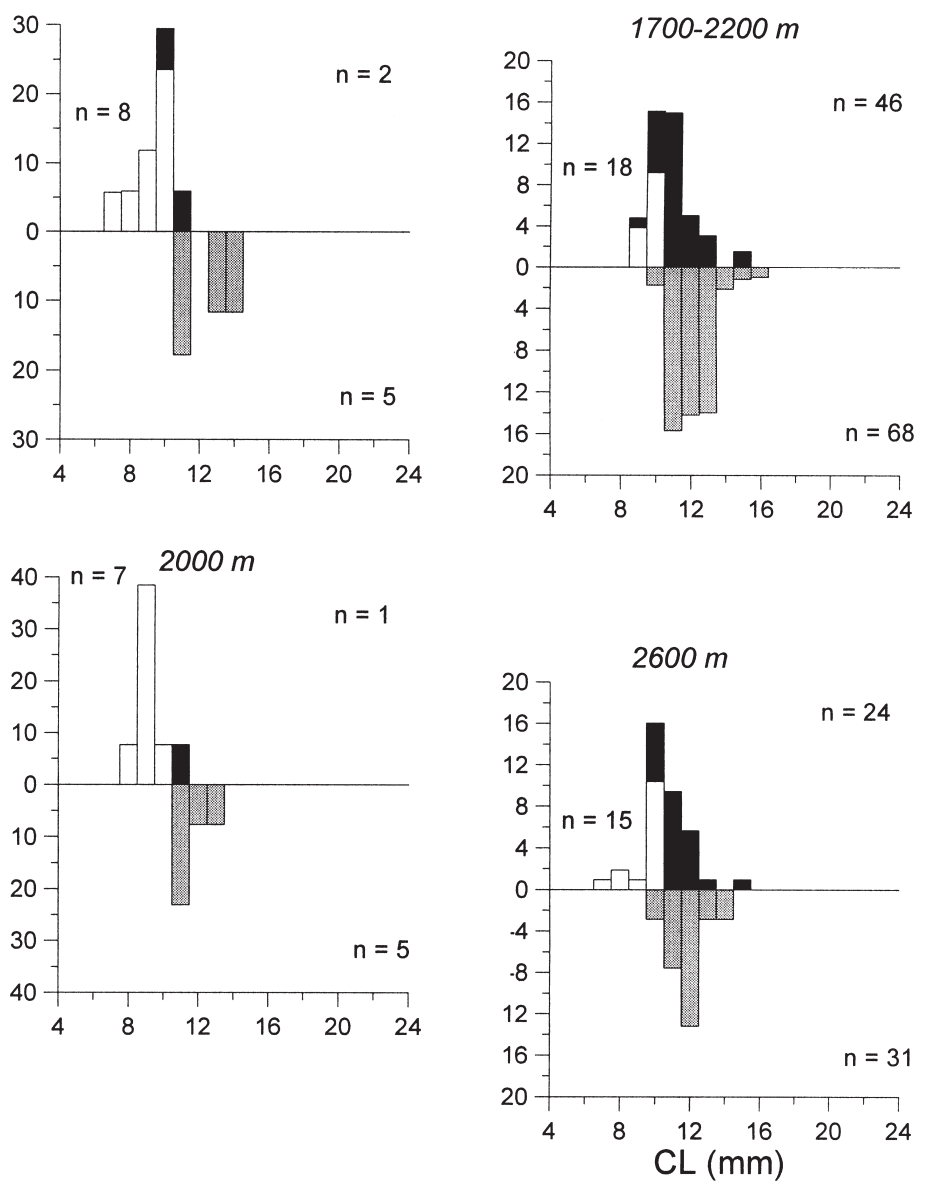

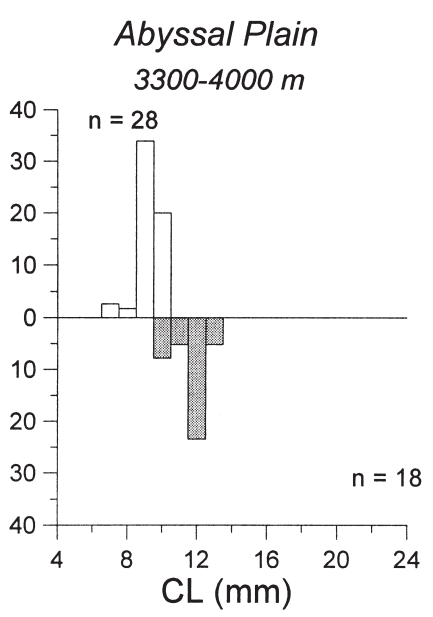

FIG. 6. - Size frequencies and sex distribution by depth interval for Nematocarcinus exilis, one of the two most abundant deep-sea decapods dwelling below $1000 \mathrm{~m}$ depth in the western and central Mediterranean Sea. White bars, indeterminate sex individuals; black bars, males; grey bars, females; $n$, number of individuals. 
lines, decapod crustacean abundance was twice that of fishes in the two abyssal samples available from this study (at 3300 and $4000 \mathrm{~m}$ ).

Megafaunal species diversity, abundance and biomass decrease with depth in the oceans worldwide (Haedrich et al., 1980; Lampitt et al., 1986). The data available for the Mediterranean are consistent with this general decrease down to $2200 \mathrm{~m}$ in the western Mediterranean (Cartes and Sardà, 1992; Stefanescu et al., 1992) and down to $1000 \mathrm{~m}$ in the Cretan Sea (Kallianiotis et al., 2000). Overall, there was a decrease in the number of species, and total decapod biomass and abundance decreased with depth in this study (down to $4000 \mathrm{~m}$; see Table 2 and Fig. 3). Although quantitative analyses were difficult to perform, mainly on account of the low number of samples, our data suggest a slight decrease in decapod biomass from the western to the eastern areas below $1000 \mathrm{~m}$ (Table 2). Unexpectedly, the eastern site yielded higher abundance and biomass values for decapod crustaceans in the shallowest portion of the depth range considered, 600-999 m. This higher abundance was mainly due to the species Aristaeomorpha foliacea. The commercial trawl fishery in the Greek Ionian Sea is carried out only down to $400 \mathrm{~m}$. Thus, bottoms below that depth are in a pristine condition in terms of fishing activity (Mytilineou et al., 2001; Papaconstantinou and Kapiris, 2001). This pristine state affects the individual size structure and abundance of $A$. foliacea as compared to the sampling area in the Italian portion of the Ionian Sea (Mytilineou et al., 2001). This same trend has been referred to elsewhere in this issue for certain bathyal fish species, e.g. Helicolenus dactylopterus, collected during the same cruise in the depth range between 600 and 800 $\mathrm{m}$, with abundance levels being twice as high in the eastern area of the Ionian Sea as in the other two sampled areas (Balearic Sea and western Ionian Sea), probably also due to the absence of fishing activity below $400 \mathrm{~m}$ (D’Onghia et al., 2004). Those workers also report a general decrease in global fish biomass with depth and a decrease in biomass from west to east, with some highly abundant species commonly reported in the western Mediterranean such as Nezumia aequalis, Centroscymnus coelolepis and Alepocephalus rostratus not being reported in the central and eastern Mediterranean or species such as Trachyrhynchus scabrus, Lepidion lepidion, Mora moro, and Cataetyx laticeps being reported only at lower biomass levels (Stefanescu et al., 1992; Galil and Goren, 1994; Kallianotis et al.,
2000; Politou et al., 2002; D’Onghia et al., 2004). The high biomass levels reported for these deep-sea fishes in the western Mediterranean do not seem to be filled by other species in the central and eastern Mediterranean.

In contrast to the situation for fishes just referred to above, the same species of deep-sea decapod crustaceans occurred across the Mediterranean sampling locations considered here. Although some species were not collected at certain locations in our study, e.g. Paromola cuvieri, Pontophilus norvegicus, and Pasiphaea multidentata, which were not caught in the easternmost area, the data published here and other available studies on species occurrence indicate that nearly the same species of deepsea decapod crustaceans are found all across the Mediterranean basin (Abelló and Valladares, 1988; Abelló et al., 1988; Cartes and Sardà, 1993; Pipitone and Tumbiolo, 1993; Galil and Goren, 1994; Ungaro et al., 1999; Kallianiotis et al., 2000; Maynou and Cartes, 2000; Politou et al., 2003; Politou et al., in press). Thus, only one species, Stereomastis sculpta, was not found in any of the sampling areas in the central Mediterranean (western and eastern Ionian Sea), and was caught only in the western Mediterranean at depths below $1500 \mathrm{~m}$. Despite the uniform species occurrence, the relative abundance and biomass of the species by area and depth interval was not homogeneous. The most significant examples were Aristeus antennatus and Aristaeomorpha foliacea. The latter species was more abundant in the eastern Ionian Sea down to $999 \mathrm{~m}$, A. antennatus being the most abundant species in the western Mediterranean and in the western Ionian Sea. In the deeper depth intervals, below $1500 \mathrm{~m}$, differences in relative abundance were observed in Nematocarcinus exilis and Acanthephyra eximia. The latter was more abundant in the western area, $N$. exilis being caught in higher proportions in the eastern area. Abundance values in the central area were similar for the two species.

All of the above-mentioned differences relating to species biomass and abundance levels should somehow correlate with a general decrease in productivity from west to east and with depth. Thus, local environmental features in a global framework have been considered to be the main factor contributing to both species biomass and relative species abundance. Fishing activity has also been considered as a factor that could affect such individual characteristics as mean size, maximum size, and species size structure (Mytilineou et al., 2001). 
Furthermore, differences in the depth distributions of the species sampled in this study (Table 3) might also be related to local environmental features. Different depth ranges for species have been attributed to different levels of primary production observed along the west to east axis across the Mediterranean (Maynou and Cartes, 2000). Thus, shallower depths of first occurrence of deep-sea decapod crustaceans have been cited in the eastern Mediterranean, associated with stronger oligotrophic conditions. However, from this study, there did not seem to be any clear trend towards shallower distribution ranges of deep-sea decapods from west to east (Table 3 ). The only species with a shallower depth of first occurrence were Plesionika acanthonotus [421 m depth in the western Mediterranean (Abelló et al., 2002c) and $317 \mathrm{~m}$ depth in the eastern Ionian Sea (Politou et al., in press)] and Chaceon mediterraneus [2261 m depth in the western Mediterranean (Cartes and Sardà, 1992) and $1700 \mathrm{~m}$ in the eastern Mediterranean]. Other species like Acanthephyra eximia, Acanthephyra pelagica, Nematocarcinus exilis, Polycheles typhlops, Geryon longipes, or even Aristaeomorpha foliacea and Aristeus antennatus, were first caught at deeper depths in the western Ionian Sea and/or eastern Ionian Sea than in the western Mediterranean. However, it is worth noting here that over the past decade greater sampling efforts have been deployed at bathyal depths in the western Mediterranean than in other areas of the Mediterranean, and all these species' depth distribution ranges could be modified substantially if more deep-sea sampling of the Mediterranean basin is performed. Thus, in our view, the observations made by Maynou and Cartes (2000) should be taken into account but should be further investigated.

Since the results of this study have shown some differential trends between the areas with regard to relative biomass and abundance and to the species' depth ranges, the final aspect remaining to be discussed is to compare how individual species structure their populations in the different areas and over the depth ranges inhabited. Local environmental features present in each of the sampling areas, including fishing pressure, could affect the characteristics of the decapod populations. From the size frequencies and sex distributions by depth interval described in this study, the intraspecific populations would seem to follow similar trends in all the areas, which seems to be unaffected by the local environmental characteristics. Thus, if local environmental features play a major role in determining the relative abundance at each depth interval and the depth distribution ranges, why do they not also affect intraspecific population structure? In our view, intraspecific population structures may be phylogenetically constrained in each individual species. Apart from the species showed in this work, Acanthephyra eximia and Nematocarcinus exilis (see Figs. 5, 6), two other species, Aristeus antennatus and Aristaeomorpha foliacea, should be taken into account due to their high abundance in the bathyal region in the three sampling areas (western Mediterranean and western and eastern Ionian Sea). Distribution and population structure data on these two species are reported in this volume (Sardà et al., 2004 and references herein; Politou et al., 2004). Juvenile A. antennatus are mainly distributed in the deepest part of this species' distribution range in the three areas studied, the largest females being distributed mainly in the shallowest part of the distribution range. Below $800 \mathrm{~m}$ in depth, the sex ratio of this species attains $50 \%$. A foliacea is very rarely caught in the western area, so comparison was only possible between the central and the eastern areas. A. foliacea presents a different distribution pattern to $A$. antennatus in terms of population structure with depth, juveniles being more abundant in the uppermost part of its distribution range in both these areas (central and eastern). This species attained a deeper depth distribution in the eastern area (see Table 2). Other abundant decapod crustaceans dwelling on the continental slope that seem to show a similar population structure throughout the Mediterranean basin are Plesionika martia, Geryon longipes, Polycheles typhlops and Parapenaeus longirostris. Biological data for Plesionika martia are widely available in the literature, especially with respect to the western Mediterranean and western Ionian Sea (Company and Sardà, 1998, 2000; Puig et al., 2001; Maiorano et al., 2002; Carbonell et al., 2003). This species does not exhibit any significant differences in size and sex distributions by depth between the three areas (Puig et al., 2001; Maiorano et al., 2002; Politou et al., 2000). Small individuals are always much more abundant in the shallowest portion of the depth distribution, and females and males are equally abundant down to $600 \mathrm{~m}$ depth, females then becoming more abundant below this depth down to the lower limit of its range. Another highly abundant deep-sea species is the crab Geryon longipes. Size frequency and sex distribution data for this crab are mainly available for the western Mediterranean 
(Company, 1995), for the western Ionian Sea (Maiorano, unpublished data) and for the Cretan Sea (Koukouras et al., 2000); at all these sites a slight decrease in mean individual size versus depth is present. Small individuals of Polycheles typhlops in the western Mediterranean were mainly distributed in the deepest portion of this species' distribution range in association with adults (Abelló and Cartes, 1992; Company, 1995). The largest individuals are mainly distributed in the shallowest portion of the depth range. A similar trend seems to be present for the individuals distributed in the western Ionian Sea (Maiorano et al., 1998). In addition, Abelló et al. (2002a) reported, in a series of trawl surveys performed over a period of six years along the upper and middle slope of the Mediterranean basin, that the size class distributions of the commercial species Parapenaeus longirostris were more related to sampling depth than to geographical area. Presumably, the limited amount of data currently available on intraspecific population structures (size frequencies and sex ratios by depth) does not fully allow us to demonstrate whether species structure their population similarly in different regions with different environmental characteristics, and if so, which constraints may play a role. Thus, further research is called for.

\section{ACKNOWLEDGEMENTS}

The DESEAS project was conducted with financial support from the Directorate for Fisheries of the European Commission to F.S. (CE Study contract 2000/39). The authors wish to thank the scientists and crew of the R/V García del Cid who were involved in carrying out this scientific project.

\section{REFERENCES}

Abelló, P., A. Abella, A. Adamidou, S. Jukic-Peladic, P. Maiorano and M.T. Spedicato. - 2002a. Geographical patterns in abundance and population structure of Nephrops norvegicus and Parapenaeus longirostris (Crustacea: Decapoda) along the European Mediterranean coasts. Sci. Mar., 66(Suppl. 2): 125141.

Abelló, P., J.A. Bertrand, L. Gil de Sola, C. Papaconstantinou, G. Relini and A. Souplet (eds.). - 2002b. Mediterranean marine demersal resources: the Medits international trawl survey (1994-1999). Sci. Mar., 66(Suppl. 2): 1-280.

Abelló, P., A. Carbonell and P. Torres. - 2002c. Biogreography of epibenthic crustaceans on the shelf and upper slope off the Iberian Peninsula Mediterranean coasts: implications for the establishment of natural management areas. Sci. Mar., 66(Suppl. 2): 183-198.

Abelló, P. and J.E. Cartes. - 1992. Population characteristics of the deep-sea lobsters Polycheles typhlops and Stereomastis sculpta
(Decapoda: Polychelidae) in a bathyal mud community of the Mediterranean Sea. Mar. Biol., 114: 109-117.

Abelló, P. and F.J. Valladares. - 1988. Bathyal decapod crustaceans of the Catalan Sea (Northwestern Mediterranean). Mésogée, 48: 97-102.

Abelló, P., F.J. Valladares and A. Castellón. - 1988. Analysis of the structure of decapod crustacean assemblages off the Catalan coast (North-West Mediterranean). Mar. Biol., 98: 39-49.

Carbonell, A., M. Palmer, P. Abelló, P. Torres, R. Alemany and L. Gil de Sola. - 2003. Mesoscale geographical patterns in the distribution of pandalid shrimps Plesionika spp. in the Western Mediterranean. Mar. Ecol. Prog. Ser., 247: 151-158.

Cartes, J.E. and F. Sardà. - 1992. Abundance and diversity of decapod crustaceans in the deep-Catalan Sea (Western Mediterranean). J. Nat. Hist., 26: 1305-1323.

Cartes, J.E. and F. Sardà. - 1993. Zonation of deep-sea decapod fauna in the Catalan Sea (Western Mediterranean). Mar. Ecol. Prog. Ser., 94: 27-34.

Company, J.B. - 1995. Estudi comparatiu de les estratègies biològiques dels crustacis decàpodes del talús de la Mar Catalana. Ph.D. thesis, Universitat de Barcelona.

Company, J.B., J.E. Cartes and F. Sardà. - 2001. Biological patterns and near-bottom population characteristics of two pasiphaeid decapod crustacean species, Pasiphaea sivado and P. multidentata, in the north-western Mediterranean Sea. Mar. Biol., 139: 61-73.

Company, J.B. and F. Sardà. - 1997. Reproductive patterns and population characteristics in five deep-water pandalid shrimps in the Western Mediterranean along a depth gradient (150-1100 m). Mar. Ecol. Prog. Ser., 148: 49-58.

Company, J.B. and F. Sardà. - 2000. Growth parameters of deepwater decapod crustaceans in the Northwestern Mediterranean Sea: a comparative approach. Mar. Biol., 136: 79-90.

Christiansen, B. - 1989. Acanthephyra sp. (Crustacea: Decapoda) in the Eastern Mediterranean Sea captured by baited traps. Senckenbergiana marit., 20: 187-193.

D'Onghia, G., C.-Y. Politou, A. Bozzano, D. Lloris, G. Rotllant, L. Sion and F. Mastrototaro. - 2004. Deep-water fish assemblages in three areas of the Mediterranean Sea. Sci. Mar. 68(Suppl. 3): 87-99.

Gage, J.D. and P.A. Tyler. - 1991. Deep-sea biology: a natural history of organisms at the deep-sea floor. Cambridge University Press, London.

Galil, B.S. and M. Goren. - 1994. The deep sea Levantine fauna. -New records and rare occurrences. Senckenberg. Marit., 25: 41-52.

Haedrich, R.L., G.T. Rowe and P.T. Polloni. - 1980. The megabenthic fauna in the deep sea south of New England, U.S.A. Mar. Biol., 57: 165-179.

Kallianiotis, A., K. Sophronidis, P. Vidoris and A. Tselepides. 2000. Demersal fish and megafaunal assemblages on the Cretan continental shelf and slope (NE Mediterranean): seasonal variation in species density, biomass and diversity. Prog. Oceanogr., 46: 429-455.

Koukouras, A. - 2000. The pelagic shrimps (Decapoda, Natantia) of the Aegean Sea, with an account of the Mediterranean species. Crustaceana, 73: 801-814.

Koukouras, A., M.-S. Kitsos and A. Tselepides. - 2000. The genera Chaceon Manning \& Holthuis and Geryon Krșyer (Decapoda, Geryonidae) in the eastern Mediterranean. Crustaceana, 73: 107-113.

Lampitt, R.S., D.S.M. Billet and A.L. Rice. - 1986. Biomass of the invertebrate megabenthos from 500 to $4100 \mathrm{~m}$ in the northeast Atlantic Ocean. Mar. Biol., 93: 69-81.

Maiorano, P., G. D’Onghia, F. Capezzuto and L. Sion. - 2002. Lifehistory traits of Plesionika martia (Decapoda: Caridea) from the eastern-central Mediterranean Sea. Mar. Biol., 141: 527539.

Maiorano, P., M. Pastore, G. D’Onghia and F. Latorre. - 1998. Note on the population structure and reproduction of Polycheles typhlops (Decapoda: Polychelidae) on the upper slope of the Ionian Sea. J. Nat. Hist., 32: 1609-1618.

Maynou, F. and J.E. Cartes. - 2000. Community structure of bathyal decapod crustacean assemblages off the Balearic Islands (south-western Mediterranean). J. Mar. Biol. Assoc. $U K$, 80: 789-798.

Mytilineou, Ch., P. Maiorano, S. Kavadas, G. D’Onghia, K. Kapiris and F. Capezzuto. - 2001. Size structure comparison in some demersal species between two areas of different fishing impact 
in the deep waters of the eastern-central Mediterranean (Ionian Sea). J, Northw. Atl. Fish. Sci., NAFO SCR Doc. 01/125.

Papaconstantinou, C. and K. Kapiris. - 2001. Distribution and population structure of the red shrimp (Aristeus antennatus) on an unexploited fishing ground in the Greek Ionian Sea. Aquat. Living Resour., 14: 303-312.

Pipitone, C. and M.L. Tumbiolo. - 1993. Decapod and stomatopod crustaceans from the trawlable bottoms of the Sicilian Channel (central Mediterranean Sea). Crustaceana, 65: 358-364.

Politou, C.-Y., M. Karkani and J. Dokos. - 2000. Distribution of Pandalid shrimps in Greek waters (Ionian Sea and Argosaronikos). In: M. Labropoulou (ed.), Proceedings of the $6^{\text {th }}$ Hellenic Symposium on Oceanography and Fisheries, Chios, II, pp. 61-66. NCMR, Athens.

Politou, C.-Y., K. Kapiris, P. Maiorano, F. Capezzuto and J. Dokos. - 2004. Deep-Sea mediterranean biology: the case of Aristaeomorpha foliacea (Risso, 1827) (Crustacea: Decapoda: Aristeidae). Sci. Mar., 68(Suppl. 3): 129-139.

Politou, C.-Y., S. Kavadas, Ch. Mytilineou, A. Tursi, R. Carlucci and G. Lembo. - 2003. Fisheries resources in the Deep waters of the Eastern Mediterranean (Greek Ionian Sea). J. Northw. Atl. Fish. Sci., 31: 35-46.

Politou, C.-Y., P. Maiorano, G. D'Onghia and Ch. Mytilineou. 2004. Deep-water decapod crustacean fauna of the Eastern Ionian Sea. Belg. J. Zool., 134 (Suppl.). In press.

Psarra, S., A. Tselepides and L. Ignatiades. - 2000. Primary productivity in the oligotrophic Cretan Sea (NE Mediterranean): seasonal and interannual variability. Prog. Oceanogr., 46: 187-204.

Puig, P., J.B. Company, F. Sardà and A. Palanques. - 2001. Responses of deep-water shrimp populations to the presence of intermediate nepheloid layers on continental margins. DeepSea Res., 48: 2195-2207.

Sardà, F., J.E. Cartes and J.B. Company. - 1994. Spatio-temporal variations in megabenthos abundance in three different habitats of the Catalan deep-sea (Western Mediterranean). Mar. Biol., 120: 211-219.

Sardà, F., J.E. Cartes, J.B. Company and A. Albiol. - 1998. A modified commercial trawl used to sample the deep-sea megabenthos. Fish. Sci., 64: 492-493.

Sardà, F., G. D'Onghia, C.-Y. Politou, J.B. Company, P. Maiorano and K. Kapiris. - 2004. Deep-sea distribution and ecological aspects of Aristeus antennatus, Risso, 1816, in the western and central Mediterranean Sea. Sci. Mar., 68(Suppl. 3): 117-127.

Stefanescu, C., D. Lloris and J. Rucabado. - 1992. Deep-living demersal fishes in the Catalan Sea (western Mediterranean) below a depth of $1000 \mathrm{~m}$. J. Nat. Hist., 26: 197-213.

Stefanescu, C., D. Lloris and J. Rucabado. - 1993. Deep-sea fish assemblages in the Catalan Sea (western Mediterranean) below a depth of $1000 \mathrm{~m}$. Deep-Sea Res., 40: 695-707.

Tselepides, A., V. Zervakis, T. Polychronaki, R. Danovaro and G. Chronis. - 2000. Distribution of nutrients and particulate organic matter in relation to the prevailing hydrographic features of the Cretan Sea (NE Mediterranean). Prog. Oceanogr., 46: 113-142.

Tselepides, A., N. Lampadariou and E. Hatziyanni. - 2004. Distribution of the meiobenthos at bathyal depths in the Mediterranean Sea. A comparison between sites of contrasting productivity. Sci. Mar., 68(Suppl. 3): 39-51.

Tyler, P.A. and R.S. Lampitt. - 1988. Submersible observations of echinoderms in the NE Atlantic Ocean. In: R. Burke (ed.), Proceedings of the Sixth International Echinoderm Conference, pp. 431-434. Balkema, Rotterdam.

Tyler, P.A. and H. Zibrowius. - 1992. Submersible observations of the invertebrate fauna on the continental slope southwest of Ireland. Oceanol. Acta, 15: 211-226.

Ungaro, N., C.A. Marano, R. Marsan, M. Martino, M.C. Marzano, G. Strippoli and A. Vlora. - 1999. Analysis of demersal species assemblages from trawl surveys in the South Adriatic Sea. Aquat. Living Resour., 13: 177-185. 